\title{
The Specificity and Significance of the Inhibition of Fc Receptor Binding by Anti H-2 Sera
}

\author{
Phil Halloran ${ }^{1}$, Volker Schirrmacher ${ }^{1}$, and Chella S. David ${ }^{2}$ \\ ${ }^{1}$ The Tissue Immunology Unit, London Hospital Medical College, London El 2 AD, England \\ ${ }^{2}$ The Department of Human Genetics, University of Michigan Medical School. \\ Ann Arbor, Michigan, 48104
}

Received March 12, 1975

\begin{abstract}
The possibility that Ia antigens are unique among $\mathrm{H}-2$ antigens in their relationship to the $\mathrm{Fc}$ receptor was investigated in an EA rosette assay. Antibody specific for antigens in various regions of the $H-2$ complex was incubated with mouse cells, and the ability of the cells to form rosettes with antibody-coated chicken erythrocytes was tested. Antibody raised against the H-2 antigens of Ia-negative tumor cells was highly effective in inhibiting rosette formation. A variety of antisera against $K-, I-$, and $D$-region antigens tested in recombinant mice inhibited EA rosette formation, suggesting that antigens in each of these regions could be detected in rosette inhibition. The $\mathrm{F}\left(\mathrm{ab} \mathrm{b}^{\prime}\right)_{2}$ fragments of all antisera tested also produced specific EA rosette inhibition. Finally, antibody against $\mathrm{Ia}$ antigens failed to inhibit bone marrow RFCs, although antibody against $\mathrm{H}-2 \mathrm{~K}$ and $\mathrm{H}-2 \mathrm{D}$ antigens did inhibit. Although $\mathrm{H}-2$ serology is in a state of rapid change at present. it must be concluded that in this assay, antibody against antigens in the $K$ and $D$ regions as well as the $I$ region can inhibit EA rosette formation. Inhibition of these rosettes by anti H-2 sera is therefore not due to a special association of $\mathrm{Ia}$ antigens with $\mathrm{Fc}$ receptors.
\end{abstract}

\section{Introduction}

The Fc receptor is a cell-surface component demonstrable on a wide variety of normal and neoplastic cells (for review see Kerbel and Davies 1974). It has potential significance in many immunologic phenomena, including cytotoxicity, allergy, regulation of the immune response, tolerance and enhancement, and others. We have been attempting to establish the relationship of the $\mathrm{Fc}$ receptor to other cell-surface components of immunogenetic interest by assessing the ability of antibody against these components to inhibit $\mathrm{Fc}$ receptor binding. That such relationships might be established in this way is suggested by a recent report in which binding of aggregated Ig to B-cell $\mathrm{Fc}$ receptors was inhibited by antibody against $I$-region antigens, implying a close association between B-cell Fc receptors and Ia antigens (Dickler and Sachs 1974).

In previous studies we demonstrated that the $\mathrm{Fc}$ receptor of cytotoxic $\mathrm{K}$ cells is not inhibited by the $\mathrm{F}\left(\mathrm{ab}^{\prime}\right)_{2}$ of anti-Ia antibody (Schirrmacher et al. $1975 \mathrm{a}, \mathrm{b}$ ), suggesting that this receptor is not identical or closely associated with Ia antigen. Furthermore it was shown that the $\mathrm{F}\left(\mathrm{ab} \mathrm{b}^{\prime}\right)_{2}$ of antibodies against Ia and other B-cell antigens inhibited rosette formation between antibody-coated erythrocytes (EA) and lymph node lymphocytes. This latter result indicated that 
EA rosette inhibition involved direct binding of the antibody to the rosetteforming cell (RFC). However, the multiplicity of the antibodies [anti-Ia, antiLy 4.2, antimouse immunoglobulin ( $\mathrm{MIg}$ ), antimouse bone-marrow-derived lymphocyte antigen (MBLA)] capable of inhibiting EA-RFC, precluded identity between $\mathrm{Fc}$ receptors and any one antigen as an explanation of the inhibition.

In the present report we examined the hypothesis that la antigens were unique among antigens of the $\mathrm{H}-2$ complex in their relationship to the $\mathrm{Fc}$ receptor. Antisera against $\mathrm{H}-2 \mathrm{~K}, \mathrm{Ia}$, and $\mathrm{H}-2 \mathrm{D}$ antigens were all found to inhibit specifically EA-RFC. The $\mathrm{F}\left(\mathrm{ab}^{\prime}\right)_{2}$ fragments from these antibodies were as strongly inhibitory as the intact antibody molecules. The immunogenetic implications of these result will be discussed.

\section{Materials and Methods}

Culture Medium. The medium was Eagle's MEM (The Wellcome Research Laboratories, Kent. England) with $0.02 \mathrm{M}$ Hepes (Wellcome) and gentamycin $(5 \mu \mathrm{g} / \mathrm{ml}$ ), and $5 \%$ fetal calf serum (Flow Laboratories, Inc., Rockville, Maryland). Rosette assays were done in $63.5 \times 9.5 \mathrm{~mm}$ round bottomed polystyrene tubes (LP/3 tubes, Luckham Limited, Burgess Hill, Sussex, England).

Animals. Young adult male and female animals were used. Strains CBA/H, BALB/c, DBA/1, DBA/2, C57BL/6, C57BL/10Sn (abbreviation B10) B10.A, B10.D2, and B10.BR were bred in the London Hospital Medical College or were obtained from the Laboratory Animal Centre, Carshalton, England. Strains B10.A(2R), B10.A(5R), B10.T(6R), B10.S(7R), HTG, A.TH, A.TL, and A.SW were bred in this laboratory from breeding pairs obtained from Dr. Peter Démant, Institute of Experimental Biology and Genetics, Praha, Czechoslovakia; from Dr. Donald C. Shreffler, University of Michigan, Ann Arbor, Michigan; and from Dr. H.O. McDevitt and Ms. B. Deak, Stanford University, Stanford, California. The $H-2$ haplotypes of the recombinant strains used are given in Table 1.

Antisera. Table 2 contains details of the anti H-2 sera used. Sera A, B, C, and G were prepared by repeated intraperitoneal injection of $10^{7}$ spleen or tumor cells at weekly intervals for 6 weeks The P815Y and Meth A tumors were obtained from the Chester Beatty Research Institute, London S.W.3 and were maintained by repeated intraperitoneal passage in DBA/2 and BALB/c mice, respectively. Sera D, E, F, H, I, J, K were obtained from the Transplantation Immunology Branch, NIAID, NIH, Bethesda, Maryland. Details of the raising and testing of these sera are contained in the

Table 1. H-2 Haplotypes of Recombinant Strains Used

\begin{tabular}{|c|c|c|c|c|c|c|c|c|}
\hline \multirow[t]{3}{*}{ Strain } & \multirow{3}{*}{$\begin{array}{l}H-2 \\
\text { Haplotype }\end{array}$} & \multicolumn{7}{|c|}{$H-2$ Regions $^{3}$} \\
\hline & & \multirow[t]{2}{*}{$K$} & \multicolumn{4}{|l|}{$I$} & \multirow[t]{2}{*}{$S$} & \multirow[t]{2}{*}{$D$} \\
\hline & & & $I-A$ & $I-B$ & $I-E$ & $I-C$ & & \\
\hline $\mathrm{B} 10 . \mathrm{A}$ & $a$ & $k$ & $k$ & $k$ & $k$ or $d$ & $d$ & $d$ & $d$ \\
\hline $\mathrm{B} 10 . \mathrm{A}(2 \mathrm{R})$ & $h 2$ & $k$ & $k$ & $k$ & $k$ or $d$ & $d$ & $d$ & $b$ \\
\hline $\mathrm{B} 10 . \mathrm{A}(5 \mathrm{R})$ & is & $b$ & $b$ & $b$ & $k$ or $d$ & $d$ & $d$ & $d$ \\
\hline $\mathrm{B} 10 . \mathrm{T}(6 \mathrm{R})$ & $y^{2}$ & $q$ & $q$ & $q$ & $q$ & $q$ & $q$ & $d$ \\
\hline B10.S(7R), A.TH & 12 & $s$ & $s$ & $s$ & s & $s$ & $s$ & $d$ \\
\hline B10.AKM & $m$ & $k$ & $k$ & $k$ & $k$ & $k$ & $k$ & $q$ \\
\hline A.TL & $t 1$ & $s$ & $k$ & $k$ & $k$ & $k$ & $k$ & $d$ \\
\hline HTG & $g$ & $d$ & $d$ & $d$ & $d$ & $d$ & $d$ & $b$ \\
\hline C3H.OL & ol & $d$ & $d$ & $d$ & $d$ & $d$ & $k$ & $k$ \\
\hline
\end{tabular}

${ }^{a}$ Shreffler and David 1975 and unpublished data. 
Table 2. Specificity of $\mathrm{H-2}$ Antisera Used

\begin{tabular}{|c|c|c|c|c|}
\hline \multirow{2}{*}{\multicolumn{2}{|c|}{ Serum }} & \multicolumn{3}{|c|}{ Potential H-2 Specificity } \\
\hline & & $H-2 K^{\mathrm{a}}$ & $I^{\mathrm{b}}$ & $H-2 D^{\mathrm{a}}$ \\
\hline & $\mathrm{CBA} / \mathrm{H}$ anti $\mathrm{BALB} / \mathrm{c}$ & (many) & $6,8,11$ & (many) \\
\hline & $\mathrm{CBA} / \mathrm{H}$ anti $\mathrm{P} 815 \mathrm{Y}$ tumor & (many) & - & (many) \\
\hline & $\mathrm{CBA} / \mathrm{H}$ anti Meth $\mathrm{A}$ tumor & (many) & - & (many) \\
\hline & $(\mathrm{B} 10 \times \mathrm{A} . \mathrm{SW}) \mathrm{F}_{1}$ anti $\mathrm{B} 10 . \mathrm{M}$ & $8,9,37$ & 1,14 & - \\
\hline & $(\mathrm{B} 10 \times \mathrm{B} 10 . \mathrm{A}) \mathrm{F}_{1}$ anti $\mathrm{B} 10 . \mathrm{D} 2$ & 31 & 11,16 & - \\
\hline & $(\mathrm{B} 10 \times \mathrm{B} 10 . \mathrm{RIII}) \mathrm{F}_{1}$ anti $\mathrm{B} 10 . \mathrm{A}(2 \mathrm{R})$ & 23 & $1,2,15$ & - \\
\hline & $(\mathrm{B} 10 \times \mathrm{C} 3 \mathrm{H} . \mathrm{OL}) \mathrm{F}_{1}$ anti $\mathrm{B} 10 . \mathrm{A}(5 \mathrm{R})$ & - & - & $4,13,41,42,43,44$ \\
\hline & $(\mathrm{B} 10 . \mathrm{AKM} \times 129) \mathrm{F}_{1}$ anti $\mathrm{B} 10 . \mathrm{A}$ & $\dot{-}$ & 6 & 4 \\
\hline & $(\mathrm{B} 10 \times \mathrm{LP} \mathrm{R}$ III $) \mathrm{F}_{1}$ anti $\mathrm{B} 10 . \mathrm{A}(5 \mathrm{R})$ & - & 15 & $4,13,41,42,43,44$ \\
\hline & $(\mathrm{B} 10 . \mathrm{BR} \times \mathrm{LP} . \mathrm{RIII}) \mathrm{F}_{1}$ anti $\mathrm{B} 10 . \mathrm{A}(2 \mathrm{R})$ & - & - & $2,28,29,56$ \\
\hline & $(\mathrm{C} 3 \mathrm{H} \cdot \mathrm{SW} \times \mathrm{HTG}) \mathrm{F}_{1}$ anti $\mathrm{C} 3 \mathrm{H}-\mathrm{H}-2^{\circ}$ & 1 & - & 1,32 \\
\hline & A.TH anti A.TL & - & $1,2,3,7,15$ & - \\
\hline & $(\mathrm{A} . \mathrm{TH} \times \mathrm{B} 10) \mathrm{F}_{1}$ anti A.TL & - & $1,2,7,15$ & - \\
\hline
\end{tabular}

${ }^{a}$ For H-2 chart see Démant 1973.

${ }^{\mathrm{b}}$ For Ia.1-10 see Shreffler and David 1975; Ia.11-16, David, unpublished data.

NIH catalogue and its 1973 and 1974 supplements (Snell 1968). The raising and testing of sera L and M were described previously (David et al. 1973, Shreffler and David 1975).

Rabbit antichicken antibody (RACA) was prepared by weekly intravenous injection of $10^{9}$ fresh washed CRBC for 5 weeks. The preparation of $\operatorname{IgG}$ and $F\left(a b^{\prime}\right)_{2}$ fragments from rabbit and mouse antisera has been described elsewhere (Schirrmacher et al. 1975a).

EA rosettes. Fresh chicken red cells were washed twice in MEM. To $1 \mathrm{ml}$ of a $2 \%$ suspension, $30 \mu \mathrm{l}$ of purified RACA IgG was added and the mixture incubated for 30 minutes at room temperature. The cells were then washed twice and resuspended in $1 \mathrm{ml}$.

Mouse spleen and lymph node cells were prepared in the usual manner. No attempt was made to remove adherent or phagocytic cells. Thymus cells were prepared by teasing thymuses, taken from young mice, through a fine mesh, taking care to remove parathymic lymph nodes. Bone marrow cells were obtained by irrigating the femoral marrow cavity with heparinized medium. All cells were washed twice and made up to $6 \times 10^{6} / \mathrm{ml}$. When rosette inhibition by antisera was to be studied. $10 \mu \mathrm{l}$ of antiserum and $500 \mu \mathrm{l}$ of cells were incubated together for 30 minutes at room temperature. Then the cells were washed once and resuspended at 3 or $6 \times 10^{6} / \mathrm{ml}$. To prepare rosettes, $50 \mu 1$ of cells, $50 \mu \mathrm{l}$ of medium, and $50 \mu \mathrm{l}$ of CRBC coated with RACA were spun down at $150 \mathrm{~g}$ for 3 minutes at $4^{\circ} \mathrm{C}$, and were kept on ice until the counting was complete. The pellet was resuspended and the number of viable mouse cells, with two or more chicken cells attached, was counted in a Neubauer counting chamber under phase-contrast illumination. Four counts of the rosette forming cells and total nucleated mouse cells were performed on each sample and the percentage of rosette forming cells was calculated. Usually 800 mouse cells were assessed per sample. The results of the rosette determinations were expressed as the arithmetic mean and standard deviation of the quadruplicate counts. The percentage of rosette-forming cells, after preincubation with antiserum, was then compared with the percentage of rosette-forming cells after preincubation with identical amounts of normal mouse serum. Other controls in the system included uncoated chicken cells plus mouse cells (which never showed rosettes) and antibody-coated chicken red cells alone (for assessment of agglutination).

\section{Results}

The EA Rosette Assay. When mouse lymph node or spleen cells were centrifuged with antibody-coated chicken red cells (EA), some of the mouse cells formed rosettes (see Fig. 1). The important parameters in this technique were: 


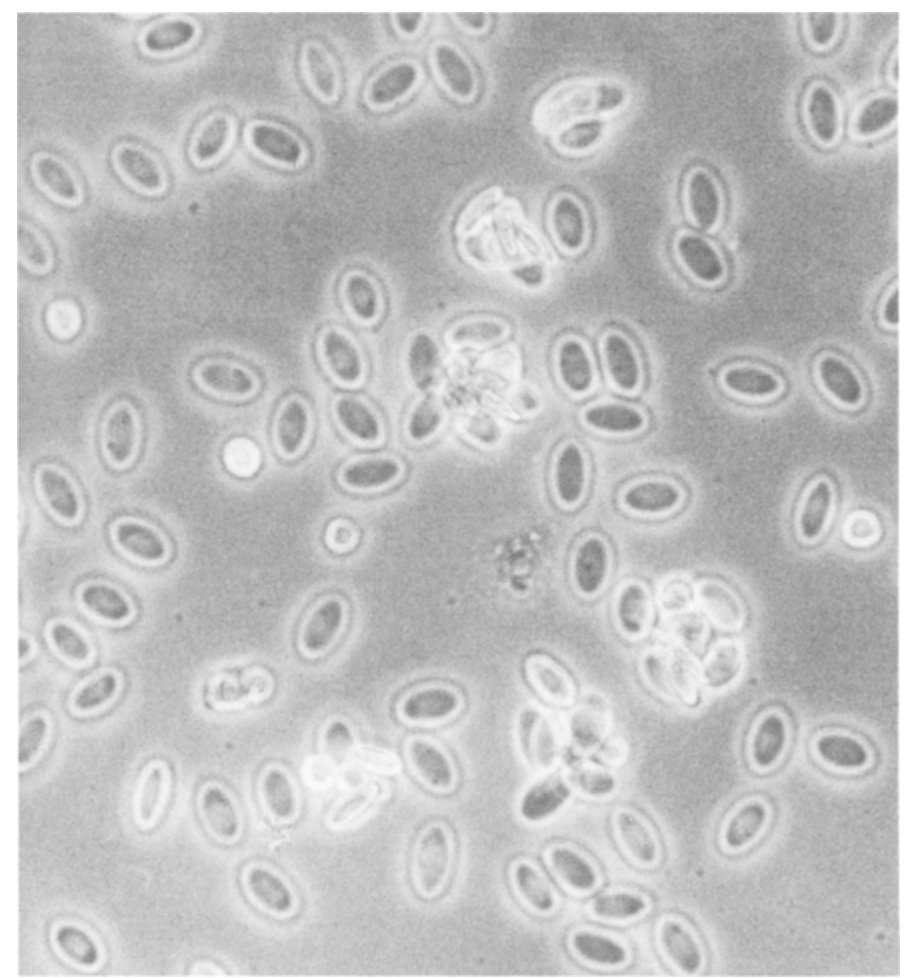

Fig. 1. Typical EA rosettes formed between mouse spleen cells and antibody-coated chicken erythrocytes. Six rosettes, several free lymphocytes, and many free chicken erythrocytes are shown

(a) purification of the antichicken erythrocyte antibody (RACA) to remove 19S antibody; (b) titration of the IgG preparation to find the highest subagglutinating concentration; (c) establishment of optimum numbers and ratios of test cells and EA. The total dependence of the rosettes on $\mathrm{Fc}$ receptor binding was demonstrated as follows: (a) when the erythrocytes were coated with RACA from which $\mathrm{Fc}$ portions had been removed by pepsin-digestion, no rosettes were formed; (b) preincubation of the rosette-forming cells with nonrelevant immune complexes or with aggregated IgG inhibited EA rosette formation.

The tissue distribution of EA-RFC was investigated. The percentage of EA-RFC found was 40 to 50 with unfractionated spleen cells, 20 to 30 with lymph node cells, 20 to 40 with bone marrow cells, and less than 1 with thymus cells. The great majority of the EA-RFC in spleen and lymph node cell preparations are small lymphocytes morphologically (probably B lymphocytes, see Discussion), whereas in bone marrow-cell preparations the majority of EA-RFC are large blast-like cells.

Inhibition of EA Rosettes by Anti-H-2 Sera with or without Anti-Ia Activity. When mouse cells are incubated with antiserum directed against their $\mathrm{H}-2$ specificities, they lose their capacity to form EA rosettes. This is illustrated in Table 3. Antiserum A, raised by injection of spleen cells, is expected to contain antibody 
Table 3. Inhibition of EA Rosettes by Anti H-2 Sera

\begin{tabular}{|c|c|c|c|c|c|}
\hline \multirow[t]{2}{*}{ Antiserum } & & \multirow{2}{*}{$\begin{array}{l}\text { Anti Ia } \\
\text { Activity } \\
\text { Present }\end{array}$} & \multicolumn{3}{|c|}{ Percent Rosette-Forming Cells ${ }^{\mathbf{a}}$} \\
\hline & & & $\mathrm{B} 10 \cdot \mathrm{BR}\left(H-2^{\mathrm{k}}\right)$ & $\mathrm{B} 10 . \mathrm{D} 2\left(H-2^{\mathrm{d}}\right)$ & $\mathrm{B} 10\left(H-2^{\mathrm{b}}\right)$ \\
\hline Normal CBA/H serum & $1 / 50$ & - & $50.8 \pm 1.5$ & $43.4 \pm 2.8$ & $49.2 \pm 3.1$ \\
\hline $\begin{array}{c}\text { A CBA } / \mathrm{H} \text { anti BALB/c } \\
\left(\mathrm{H}-2^{k} \text { anti } \mathrm{H}-2^{\mathrm{d}}\right)\end{array}$ & $1 / 50$ & + & $54.6 \pm 2.3$ & $2.5 \pm 0.9$ & $21.5 \pm 1.5$ \\
\hline $\begin{array}{c}\mathrm{B} \mathrm{CBA} / \mathrm{H} \text { anti P-815Y } \\
\left(\mathrm{H}-2^{\mathrm{k}} \text { anti } \mathrm{H}-2^{\mathrm{d}}\right)\end{array}$ & $1 / 50$ & - & $48.5 \pm 5.6$ & $4.8 \pm 1.2$ & $39.0 \pm 2.8$ \\
\hline $\begin{array}{c}\text { C CBA/H anti-Meth A } \\
\left(\mathrm{H}-2^{\mathrm{k}} \text { anti-H- } 2^{\mathrm{d}}\right)\end{array}$ & $1 / 50$ & - & $48.5 \pm 1.0$ & $1.0 \pm 0.8$ & $20.5 \pm 2.5$ \\
\hline
\end{tabular}

${ }^{a}$ Spleen cells pretreated with antiserum and washed.

against $\mathrm{H}-2 \mathrm{D}, \mathrm{H}-2 \mathrm{~K}$, and Ia antigens. Preincubation with antiserum $\mathrm{A}$ (anti- $\mathrm{H}-2^{\mathrm{d}}$ ) completely blocks EA rosette formation by B10.D2 $\left(H-2^{\mathrm{d}}\right)$ but has no effect on $\mathrm{B} 10 . \mathrm{BR}\left(H-2^{\mathrm{k}}\right)$ cells. The intermediate effects on the $\mathrm{B} 10\left(H-2^{\mathrm{b}}\right)$ cells is predicted from the public (and Ia) specificities shared between $H-2^{\mathrm{d}}$ and $H-2^{\mathrm{b}}$ (Démant 1973, Shreffler and David 1975). To assess the importance of anti-Ia activity on the inhibition observed, the anti-H-2 sera raised were tested against the Ianegative tumor cells mastocytoma P815Y and T-cell lymphoma Meth $\mathrm{A}^{1}$. Both of these antisera (B and $C$ ) strongly inhibited EA rosette formation (Table 3) suggesting that antibody against $\mathrm{H}-2 \mathrm{D}$ or $\mathrm{H}-2 \mathrm{~K}$ antigens can inhibit EA rosette formation.

Inhibition of EA Rosettes by Anti-sera Against H-2K, Ia, or H-2D antigens. To establish conclusively the specificity of the inhibitory activity in anti- $\mathrm{H}-2$ sera, well-defined sera were assessed with restricted specificity against panels of lymph node cells from strains selected to express all, some, or none of the immunizing $\mathrm{H}-2$ antigens. The results are shown in Tables 4, 5, 6, and 7.

Table 4. Specificity of EA Rosette Inhibition by Anti H-2 Sera

\begin{tabular}{|c|c|c|c|c|c|c|c|c|c|c|c|}
\hline \multicolumn{8}{|c|}{ Source of Test Cells } & \multicolumn{4}{|c|}{ Percent Rosette-Forming Cells } \\
\hline \multirow[t]{3}{*}{ Strain } & \multicolumn{7}{|c|}{ Relevant H-2 Antigens } & \multirow[t]{3}{*}{ Control } & \multicolumn{3}{|c|}{ After Treatment with Antiserum } \\
\hline & \multicolumn{2}{|c|}{$\mathrm{H}-2 \mathrm{~K}$} & \multicolumn{4}{|l|}{ Ia } & \multirow{2}{*}{$\frac{H-2 D}{4}$} & & \multirow{2}{*}{$\begin{array}{l}\mathrm{H} \\
\text { (Anti- } \\
\mathrm{H}-2 \mathrm{D} .4, \\
\text { la.6) }\end{array}$} & \multirow{2}{*}{$\begin{array}{l}\text { D } \\
\text { (Anti- } \\
\text { H-2K.8, } \\
\text { Ia.1) }\end{array}$} & \multirow{2}{*}{$\begin{array}{l}\text { F } \\
\text { (Anti- } \\
\text { H-2K.23, } \\
\text { Ia. 1, 2,15) }\end{array}$} \\
\hline & 8 & 23 & 1 & 2 & 6 & 15 & & & & & \\
\hline $\mathrm{B} 10$ & - & - & - & - & - & - & - & $24.5 \pm 2.9$ & $27.5 \pm 2.0$ & $25.5 \pm 3.0$ & $26.7 \pm 1.8$ \\
\hline B10.A & + & + & + & + & + & + & + & $25.1 \pm 1.2$ & $2.0 \pm 1.1$ & $3.0 \pm 1.7$ & $3.4 \pm 0.4$ \\
\hline $\mathrm{B} 10 . \mathrm{A}(2 \mathrm{R})$ & + & + & + & + & + & + & - & $19.9 \pm 1.5$ & $21.1 \pm 2.5$ & $3.2 \pm 1.0$ & $1.1 \pm 0.3$ \\
\hline A.TL & - & - & + & + & - & + & + & $18.6 \pm 3.3$ & $3.4 \pm 1.5$ & $19.7 \pm 2.9$ & $14.1 \pm 2.3$ \\
\hline
\end{tabular}

${ }^{a}$ Lymph node cells were preincubated at serum concentration 1:50 for 30 minutes at room temperature. The cells were then washed once and the rosette assay was performed.

1 These $H-2^{\text {d }}$ tumors did not have Ia.6, 7 or 15 when tested in a complement-dependent lysis assay (CDL). Although small amounts of anti-Ia antibody might still theoretically occur, due to the small numbers of lymphocytes contaminating the injected tumor cells, the authors have not been able to demonstrate such reactions in appropriate recombinant mice. 
Table 5. Specificity of EA Rosette Inhibition by Anti H-2 Sera

\begin{tabular}{|c|c|c|c|c|c|c|c|c|c|c|c|c|}
\hline \multicolumn{8}{|c|}{ Source of Test Cells } & \multicolumn{5}{|c|}{ Percent Rosette-Forming Cells } \\
\hline \multirow[t]{3}{*}{ Strain } & \multicolumn{7}{|c|}{ Relevant H-2 Antigens } & \multirow[t]{3}{*}{ Control } & \multicolumn{4}{|c|}{ After Treatment with Antiserum ${ }^{a}$} \\
\hline & \multirow{2}{*}{$\underline{\mathrm{H}-2 \mathrm{~K}}$} & \multicolumn{3}{|l|}{ Ia } & \multicolumn{3}{|c|}{$\mathrm{H}-2 \mathrm{D}$} & & \multirow{2}{*}{$\begin{array}{l}\text { L } \\
\text { (Anti- } \\
\text { Ia.3) }\end{array}$} & \multirow{2}{*}{$\begin{array}{l}\text { G } \\
\text { (Anti- } \\
\text { H-2D.4. } \\
13,42)\end{array}$} & \multirow{2}{*}{$\begin{array}{l}\mathrm{H} \\
\text { (Anti- } \\
\text { H-2D.4, } \\
\text { Ia.6) }\end{array}$} & \multirow{2}{*}{$\begin{array}{l}\text { I } \\
\text { (Anti- } \\
\text { H-2D.4, } \\
\text { 13,42, Ia.15) }\end{array}$} \\
\hline & & 3 & 6 & 15 & 4 & 13 & 42 & & & & & \\
\hline B10 & - & + & - & - & - & - & - & $24.5 \pm 2.4$ & $1.1 \pm 0.6$ & $23.0 \pm 2.2$ & $23.5 \pm 2.3$ & 26.7 \\
\hline A.SW & - & - & - & - & - & - & + & $22.8 \pm 1.3$ & $22.5 \pm 1.1$ & $14.8 \pm 3.3$ & $23.1 \pm 3.9$ & $14.8 \pm 0.9$ \\
\hline $\mathrm{B} 10 . \mathrm{S}(7 \mathrm{R})$ & - & - & - & - & + & + & + & $25.0 \pm 1.4$ & $22.8 \pm 2.4$ & $2.0 \pm 0.6$ & $4.8 \pm 0.9$ & $1.2 \pm 0.6$ \\
\hline
\end{tabular}

"See footnote a, Table 4.

Table 6. Specificity of EA Rosette Inhibition by Anti H-2 Sera

\begin{tabular}{|c|c|c|c|c|c|c|c|c|c|c|c|c|c|}
\hline \multicolumn{9}{|c|}{ Source of Test Cells } & \multicolumn{5}{|c|}{ Percent Rosette-Forming Cells } \\
\hline \multirow[t]{3}{*}{ Strain } & \multicolumn{8}{|c|}{ Relevant $\mathrm{H}-2$ Antigens } & \multirow[t]{3}{*}{ Control } & \multicolumn{4}{|c|}{ After treatment with Antiserum } \\
\hline & \multirow{2}{*}{$\frac{\mathrm{H}-2 \mathrm{~K}}{31}$} & \multicolumn{5}{|l|}{$\mathrm{Ia}$} & \multicolumn{2}{|c|}{$\mathrm{H}-2 \mathrm{D}$} & & \multirow{2}{*}{$\begin{array}{l}\text { M } \\
\text { (Anti- } \\
\text { Ia.7, 15) }\end{array}$} & \multirow{2}{*}{$\begin{array}{l}\mathrm{G} \\
\text { (Anti- } \\
\mathrm{H}-2 \mathrm{D} .4 \\
13 \text { ) }\end{array}$} & \multirow{2}{*}{$\begin{array}{l}\mathrm{H} \\
\text { (Anti- } \\
\text { H-2D.4, } \\
\text { Ia.6) }\end{array}$} & \multirow{2}{*}{$\begin{array}{l}\mathrm{E} \\
\text { (Anti- } \\
\text { H-2K.31, } \\
\text { Ial1.16) }\end{array}$} \\
\hline & & 6 & 7 & 11 & 15 & 16 & 4 & 13 & & & & & \\
\hline $\mathrm{B} 10$ & - & - & - & - & - & - & - & - & 26.8 & $27.8 \pm 2.6$ & $26.2 \pm 0.6$ & $28.6 \pm 0.2$ & 28.4 \\
\hline $\mathrm{B} 10 . \mathrm{D} 2$ & + & + & + & + & + & + & + & + & $31.8 \pm 0.9$ & $8.6 \pm 0.7$ & $3.2 \pm 0.4$ & $6.1 \pm 0.7$ & $0.9 \pm 0.2$ \\
\hline HTG & + & t & + & + & + & + & - & -- & $19.7 \pm 0.8$ & $6.7 \pm 2.0$ & $19.4 \pm 4.5$ & $17.7 \pm 3.5$ & $1.4 \pm 0.8$ \\
\hline $\mathrm{B} 10 . \mathrm{T}(6 \mathrm{R})$ & - & - & - & - & - & + & + & + & $24.1 \pm 0.5$ & $25.8 \pm 1.6$ & $3.0 \pm 1.8$ & $8.0 \pm 0.7$ & $20.0 \pm 3.4$ \\
\hline $\mathrm{DBA} / 1$ & - & - & - & - & - & + & - & + & $20.5 \pm 1$ & $17.4 \pm 2.4$ & $4.0 \pm 0.5$ & $19.0 \pm 0.5$ & $13.0 \pm 1.9$ \\
\hline
\end{tabular}

a See footnote a. Table 4.

EA rosette inhibition by anti-H-2 $\mathrm{K}$ antibody is shown by serum $\mathrm{D}$ (anti-H2 K.8; Table 4). The weak anti-Ia.1 activity in this serum is undetectable at the dilution tested. Furthermore, with antiserum $\mathrm{E}$ (anti-H-2 K.31, Ia.11, 16; Table 6) and serum F (anti-H-2 K.23, Ia.1, 2, 15; Table 4) cells with the relevant $\mathrm{H}-2 \mathrm{~K}$ antigens are clearly inhibited more strongly than are cells lacking some or all of these antigens. With serum $\mathrm{E}$ however, the relative importance of $\mathrm{H}-2 \mathrm{~K} .31$ and Ia.11 in producing the inhibition observed cannot be resolved. The activity in this serum previously felt to be H-2K.34 is now attributed to Ia.16 (N. Staines, personal communication).

The ability of anti H-2D sera to inhibit EA-rosettes is demonstrated by serum G (anti H-2D.4, 13, 42; Tables 5 and 6); serum H (anti-H-2 D.4; Tables 4, 5 , and 6); serum I (anti-H-2D.4, 13, 42; Ia.15; Table 5); and serum J (anti-H2 D.28, 29; Table 7). Only antibody against $D$-region antigens can account for the pattern of inhibition observed. Serum G is particularly important since it was not raised across any known $I$-region differences.

Antibody raised against some $D$-region antigens can react with similar antigens in the $K$ region. The occurence of such a result in rosette inhibition is shown by serum $\mathrm{K}$ (anti $\mathrm{H}-2 \mathrm{KD} .1$; Table 7 ). As with serum $\mathrm{G}$ the raising of this serum 
Table 7. Specificity of EA Rosette Inhibition by Anti H-2 Sera

\begin{tabular}{|c|c|c|c|c|c|c|c|c|c|}
\hline \multicolumn{7}{|c|}{ Source of Test Cells } & \multicolumn{3}{|c|}{ Percent Rosette-Forming Cells } \\
\hline \multirow[t]{3}{*}{ Strain } & \multicolumn{6}{|c|}{ Relevant $\mathrm{H}-2$ Antigens } & \multirow[t]{3}{*}{ Control } & \multicolumn{2}{|c|}{ After Treatment with Antiserum } \\
\hline & \multirow{2}{*}{$\frac{\mathrm{H}-2 \mathrm{~K}}{1}$} & \multirow{2}{*}{$\underline{\mathrm{Ia}}$} & \multicolumn{4}{|c|}{$\mathrm{H}-2 \mathrm{D}$} & & \multirow{2}{*}{$\begin{array}{l}\text { J } \\
(\text { Anti-H-2D, } \\
28,29)\end{array}$} & \multirow{2}{*}{$\begin{array}{l}\text { K } \\
\text { (Anti-H-2D.32, } \\
\text { H-2KD.1) }\end{array}$} \\
\hline & & & $\overline{1}$ & 28 & 29 & $\overline{32}$ & & & \\
\hline $\mathrm{B} 10 . \mathrm{D} 2$ & - & - & - & + & + & - & $24.1 \pm 4.3$ & $8.3 \pm 1.0$ & $22.5 \pm 1.9$ \\
\hline B10.BR & + & - & + & - & - & + & $25.6 \pm 2.0$ & $23.5 \pm 2.0$ & $1.6 \pm 1.0$ \\
\hline B10.A & + & - & - & + & + & - & $20.8 \pm 2.8$ & $4.8 \pm 0.8$ & $4.5 \pm 1.1$ \\
\hline $\mathrm{B} 10 . \mathrm{AKM}$ & + & - & + & + & + & - & $20.0 \pm 2.2$ & $2.8 \pm 0.3$ & $7.0 \pm 2.0$ \\
\hline
\end{tabular}

${ }^{a}$ See footnote a, Table 4.

involved no known $I$-region differences and no known Ia-Antigen differences.

The inhibition of EA-rosette formation by anti-Ia antisera has been previously reported (Schirrmacher et al. 1975a) and is re-emphasized by the results obtained with serum L (anti-Ia.1, 2, 3, 7, 15; Table 5) and serum $M$ (anti-Ia.1, 2, 7, 15; Table 6). Several other reactions in the anti-H-2 sera shown in these tables may be attributed to Ia activity.

Thus all anti-H-2 sera in which antibody was easily demonstrable by conventional methods (CDL) produced specific inhibition of EA rosettes, irrespective of whether the antibody was directed against $K-, I-$, or $D$-region antigens. No unique association between EA rosette inhibition and antibody against I-region antigens was found in our system.

Comparison of IgG and $\mathrm{F}\left(a b^{\prime}\right)_{2}$ Preparations of Anti-H-2 Sera in EA Rosette Inhibition. To show that inhibition of rosette formation was due to direct binding of the antibody combining sites to the RFC, the IgG and $\mathrm{F}\left(\mathrm{ab}^{\prime}\right)_{2}$ preparations of various anti $\mathrm{H}-2$ antisera were tested in parallel. The results, illustrated in Fig. 2, showed that there were no significant differences between the inhibitory potency of the intact $\mathrm{IgG}$ molecules and that of their $\mathrm{F}\left(\mathrm{ab}^{\prime}\right)_{2}$ fragments. This was true whether the antibody was directed against Ia(a), H-2 D(b), or H-2 K(c) antigens.

The Inhibition of RFC Obtained from Different Tissues by Anti-H-2 Antisera. Table 8 illustrates an experiment in which cells from various tissues (thymus, lymph node, spleen and bone marrow) were preincubated with antiserum and then assessed for their ability to form EA rosettes. Bone marrow cells were of particular interest because the great majority lack Ia antigens (McDevitt et al. 1974). RFC from lymph node and spleen cells were almost completely inhibited by either anti-Ia serum (L) or anti-H-2 D serum (G). The RFC of bone marrow were also inhibited by anti H-2D serum, but they were not inhibited by anti-Ia serum. Similar results were obtained when anti-H-2 K and -Ia antisera were compared - the anti-H-2 K serum (E) strongly inhibited bone marrow RFC, whereas anti-Ia did not. These results show that (a) our anti-H-2 K and anti $\mathrm{H}-2 \mathrm{D}$ sera do recognise antigens, the tissue distribution of which conforms with that of the conventional $\mathrm{H}-2 \mathrm{~K}$ and $\mathrm{H}-2 \mathrm{D}$ antigens, not with that of the Ia antigens; (b) the Fc receptor on the bone marrow $\mathrm{RFC}$ is not associated with Ia antigens. 


\section{control strain test strain}

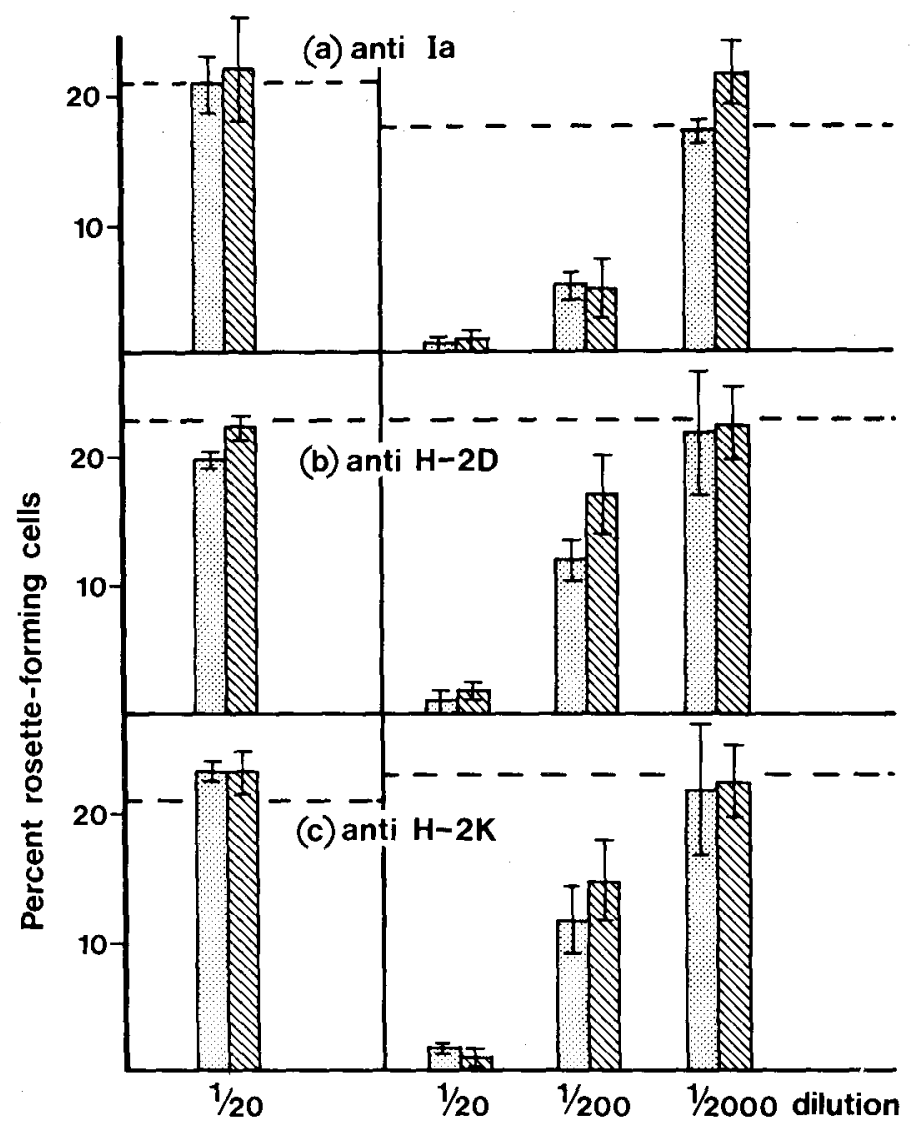

Fig. 2. Comparison of the EA rosettes observed with lymph node cells after no treatment (broken lines) or after treatment with the IgG preparation (stippled bars) or the $F\left(a b^{\prime}\right)_{2}$ preparation (hatched bars) of various antisera. (a) Anti-Ia (serum $\mathrm{M}$ ); the control strain was B10 and the test strain was B10.A; (b) Anti-H-2D (serum G); the control strain was B10 and the test strain was B10.D2; (c) Anti-H-2 K (serum E); the control strain was B10 and the test strain was B10.D2. This serum also contains anti-Ia activity

Table 8. Inhibition of Rosette-Forming Cells from Different Tissues of B10.A Mice by Anti-H-2 Sera

\begin{tabular}{llll}
\hline Source of Cells & \multicolumn{2}{l}{ Percent Rosette-Forming Cells } \\
\cline { 2 - 4 } & Control & \multicolumn{2}{c}{ After Treatment with Antiserum } \\
\cline { 3 - 4 } & & L & G \\
& & (Ia $1,2,3,7,15)$ & (Anti-H-2D.4,13) \\
\hline Thymus & $0.2 \pm 0.2$ & $\mathrm{NT}^{\mathrm{b}}$ & $\mathrm{NT}$ \\
Lymph node & $33.3 \pm 6.3$ & $1.8 \pm 1.0$ & $2.4 \pm 1.0$ \\
Spleen & $46.0 \pm 3.6$ & $6.0 \pm 1.9$ & $2.7 \pm 0.6$ \\
Bone marrow & $40.6 \pm 2.7$ & $39.6 \pm 1.0$ & $4.1 \pm 1.2$ \\
\hline
\end{tabular}

\footnotetext{
a See footnote a, Table $4 . \quad$ b NT $=$ not tested.
} 
Table 9. Comparison of Cytotoxicity Inhibition and EA Rosette Inhibition by Antisera

\begin{tabular}{|c|c|c|c|c|}
\hline \multirow[t]{2}{*}{ Antiserum Tested } & \multicolumn{2}{|c|}{$\begin{array}{l}\text { Inhibition of Antibody-Dependent } \\
\text { Cell-Mediated Cytotoxicity }\end{array}$} & \multicolumn{2}{|c|}{$\begin{array}{l}\text { Inhibition of } \\
\text { EA Rosettes } \\
\end{array}$} \\
\hline & $\mathrm{IgG}$ & $\mathrm{F}\left(\mathrm{ab} \mathrm{b}^{\prime}\right)_{2}$ & $\operatorname{IgG}$ & $F\left(a b^{\prime}\right)_{2}$ \\
\hline \multicolumn{5}{|l|}{$\begin{array}{l}\text { Alloantisera } \\
\text { (a) anti-H-2 }\end{array}$} \\
\hline $\mathrm{A}$ anti-H-2K or $\mathrm{D}$ & + & - & + & + \\
\hline $\mathrm{B}$ anti-Ia & + & - & + & + \\
\hline (b) anti-Thy 1.2 & + & - & - & - \\
\hline (c) anti-Ly 4.2 & + & - & + & $+^{c}$ \\
\hline Rabbit Anti-MIg & + & - & + & + \\
\hline Rabbit Anti-MBLA & + & - & + & + \\
\hline Rabbit Anti-BA $\theta^{\mathrm{d}}$ & + & - & - & - \\
\hline
\end{tabular}

${ }^{a}$ Using spleen effector cells (Halloran et al. 1974).

${ }^{\mathrm{b}}$ Using lymph node or spleen RFC.

c Schirrmacher and Hallovan, 1975, manuscript in preparation.

${ }^{\mathrm{d}}$ BA $\theta=$ brain associated Thy-1 $(\theta)$.

\section{Discussion}

Inhibition of an $\mathrm{Fc}$ receptor-dependent assay by antibody against the $\mathrm{Fc}_{\mathrm{c}}$ receptor-bearing cells may be due to several potential mechanisms: (a) the antibody may be binding to the Fc receptor by its Fc portion; (b) the antibody may be producing membrane changes that could alter the ability of the Fc receptor to bind; (c) the antibody might bind to a site on the cell membrane remote from the Fc receptor, but might still be able to exert steric effects, particularly in assays where the binding of large aggregates or erythrocytes was required; (d) the antibody might be binding directly to antigens intimately associated with the $\mathrm{Fc}$ receptor. Until one establishes which of these mechanisms is causing the inhibition of an Fc receptor-dependent event one cannot assign an immunogenetic significance to the phenomenon.

There are numerous techniques for the detection of Fc receptors: (a) EA rosettes (Cline et al. 1972), (b) binding of labeled immune complexes (Basten et al. 1972a,b, Yoshida and Anderson 1972, Eden et al. 1973) or aggregated IgG (Dickler and Sachs 1974, Anderson and Grey 1974); (c) binding of antibodycoated erythrocytes to tissue sections (hemabsorption) (Tønder and Thunøld 1973); (d) inhibition of reverse immune cytoadherence (RICA) (Paraskevas et al. 1972a); (e) ingestion of antibody-coated erythrocytes by macrophages (Holland et al. 1972);(f) antibody-dependent cell-mediated cytotoxicity (ADCC; MacLennan et al. 1973). The homogeneity of the Fc receptors detected by these different assays has not been established.

In many of these systems antibodies directed against the Fc receptor-bearing cell population have been reported to inhibit $\mathrm{Fc}$ receptor-binding in vitro. The inhibition of aggregated immunoglobulin or immune complex binding by anti-Ia sera and their Fab fragments has been mentioned in the introduction. In rats, EA rosettes have been inhibited by anti-AgB antibody (Parish and Hayward $1974 \mathrm{~b}$ ). Heterologous antihuman lymphoma serum inhibited hemabsorption to 
human lymphoma tissue (Tønder and Thunøld 1973), and heterologous antimouse lymphocyte serum has been reported to inhibit the detection of $\mathrm{Fc}$ receptors by the RICA inhibition technique (Paraskevas et al. 1972 b). A variety of heterologous antisera inhibit the ingestion of antibody-coated erythrocytes by macrophages, apparently by an Fc-dependent mechanism (Holland et al. 1972). The relationship of each of these phenomena to the others is not clear, and at least two different mechanisms may be operating: an Fc-dependent mechanism, as in the inhibition of phagocytosis, and an Fc-independent mechanism, as in the inhibition of aggregate binding by anti-Ia sera.

In previous studies of antibody-dependent cell-mediated cytotoxicity, we have reported that antibody against a wide variety of cell-membrane antigens produced inhibition when allowed to interact with the effector cell population (Halloran and Festenstein 1974, Halloran et al. 1974). The mechanism of this inhibition seemed to involve the formation of antibody-cell complexes, the Fc portions of which bound to the $\mathrm{Fc}$ receptor of the effector cell to inhibit cytotoxicity. The $F\left(a b^{\prime}\right)_{2}$ fragments of these antibodies, including anti-Ia antibodies, produced no inhibition (Schirrmacher et al. $1975 \mathrm{a}, \mathrm{b}$ ). As mentioned in the Introduction, a wide variety of antibodies against B cells inhibited EA rosette formation by lymph node and spleen cells, but in contrast to the situation with cytotoxicity inhibition, the $\mathrm{F}\left(\mathrm{ab}^{\prime}\right)_{2}$ fragments of these antibodies also produced strong EA rosette inhibition. The present studies were undertaken to establish whether the inhibition observed with antisera against $\mathrm{H}-2$ antigens could be exclusively due to antibody against I-region antigens.

The EA rosette forming cells in our system are of two varieties: (a) a $B$ lymphocyte, which represents the vast majority of RFC in lymph node and spleen, as shown by tissue distribution, nylon fiber column removal, resistance to anti-Thy- 1 and complement treatment (unpublished results), and inhibition by antibodies against B cells (MBLA; MIg; Ia; Ly 4.2) but not by antibodies against $T$ cells (Schirrmacher et al. 1975 b); (b) a population of bone marrowderived cells, usually large and blast like, the properties of which are under investigation but which probably belong to the myeloid lineage of cells. In this report antibodies against $K$ - or $D$-region antigens have been shown to inhibit both of these types of RFC but that antibodies against $I$-region antigens can inhibit only the B-lymphocyte RFC. This corroborates previous observations about the absence of $I$-region antigens on the vast majority of bone marrow cells. It may be pertinent that small numbers of cells in spleen, and to a lesser extent in lymph nodes, are resistant to inhibition, especially with anti-Ia antisera, and probably represent other cell types (particularly macrophages).

The mechanism of inhibition of EA-RFC by anti-H-2 or other antisera is not known. It is independent of the $\mathrm{Fc}$ portion of the inhibiting antibody, since the $F\left(a b^{\prime}\right)_{2}$ fragment is equal, or almost equal, to the whole IgG molecule (Fig. 2). Furthermore, it cannot be attributed to identity between cell-surface antigens and $\mathrm{Fe}$ receptors, because antibodies to such a wide variety of independent antigens have been shown to be inhibitory. Metabolic activity seems unnecessary, since the reaction can occur at $4^{\circ} \mathrm{C}$. Steric hindrance of cell-to-cell contact is a possible explanation, yet it fails to account for the failure of antisera, which inhibit EA rosettes, to inhibit complement-receptor rosettes (Parish and Hayward 
1974, Dickler and Sachs 1974) or rosettes formed between B cells and anti-immunoglobulin-coated erythrocytes (Parish and Hayward 1974). A completely satisfactory explanation is probably not possible at present.

We emphasize the difference between the inhibition of EA rosettes by antisera and the inhibition of ADCC by similar antisera (the cytotoxicity inhibition assay or CIA), as summarized in Table 9. Whether these differences reflect differences in the conditions of the two assays, in the cells bearing the Fc receptors, or in the structure or behavior of the Fc receptors themselves is an interesting but unresolved question. Particularly attractive is the possibility that the Fc receptors detected in cytotoxicity and those detected in EA rosette formation may have different functional properties.

As reported by Dickler and Sachs (1974), binding of aggregated Ig to the $\mathrm{B}$-cell Fc receptor could not be inhibited by antibody against $\mathrm{H}-2 \mathrm{~K}$ or $\mathrm{H}-2 \mathrm{D}$ antigens, but only by antibody against Ia antigens. In contrast, we have found that antibody against some antigens apparently mapping in the $K$ or $D$ regions is as effective as antibody against $I$-region antigens in the EA rosette-inhibition assay when the RFC is a B lymphocyte. Definitive interpretation of the results, particularly for the $\mathrm{H}-2 \mathrm{~K}$ antigens, is complicated by the recent rapid changes in the understanding of serological specificities in the $H-2$ system. Some specificities currently believed to be $\mathrm{H}-2 \mathrm{~K}$ antigens are being reassessed as $I$-region antigens, and the knowledge of crossover positions in recombinant mice is still developing. It may be assumed that some of the antisera employed in the studies reported herein will contain antibody against currently unknown $I$-region antigens.

But can the inhibition observed with the antisera against $\mathrm{H}-2 \mathrm{~K}$ and $\mathrm{H}-2 \mathrm{D}$ antigens be attributed to undiscovered Ia antigens? Certainly the reactions of the antisera against $D$-end antigens with cells from the recombinants between the $S$ and $D$ regions [B10.A(2R), B10.T(6R), B10.S(7R), B10.AKM and HTG] cannot be attributed to $I$-region antigens. Nor can $I$-region antigens account for the crossreaction shown between the $D$-end and $K$-end antigens in our results. The strong inhibition shown with anti-H-2 sera raised against Ia-negative tumor cells, and the ability of antisera against $K$ - and $D$-region antigens to inhibit bone marrow RFCs (most of which lack Ia antigens and which are not inhibited by anti-Ia antisera) must imply that the antigens detected lack the restricted tissue distribution characteristic of Ia antigens. The only coherent explanation of all of these results is that antibody against at least some $K$ - and $D$-region antigens, as well as antibody against $I$-region antigens, against MBLA, Ly 4.2, and mouse immunoglobulin, can inhibit EA rosette formation. Whether antibody against every cell-surface antigen on the rosette-forming cell can mediate EA rosette inhibition in our system and whether the $\mathrm{H}-2 \mathrm{~K}$ and $\mathrm{H}-2 \mathrm{D}$ antigens involved are the same as those expressed on red cells, cannot be resolved at present.

In concluding, we would like to emphasize certain points of immunogenetic interest. First, conclusions about the Fc receptor and its relationship to Ia antigens are difficult to assess by inhibition data alone. The fact that antisera against many different surface antigens inhibit our EA rosette system does not deny that in another type of EA rosette or aggregate-binding system, antibody against Ia antigens may have unique characteristics. But until the mechanism of the inhibition of $\mathrm{Fc}$ receptors in the various systems is resolved, concluding that 
the Fc receptor is uniquely associated with $I$-region gene products is hazardous. Certainly it would now seem that $\mathrm{Fc}$ receptors which are not inhibited by anti-Ia antibody, are present on several cell types: bone marrow cells (this report); cytotoxic effector cells (Schirrmacher et al. 1975b); and some tumor cells (P.H., unpublished; Ramasamy and Munroe, personal communication).

Second, most antisera that reacted with the rosette-forming cells in conventional assays have thus far inhibited EA-rosette formation, suggesting that this EA-rosette inhibition may prove to be a convenient method for studying cellsurface antigens on various kinds of EA rosette-forming cells. For example, we are currently employing this method to study cell-surface antigens on the subpopulation of activated $\mathrm{T}$ cells, which expresses $\mathrm{Fc}$ receptors (Yoshida and Anderson 1972).

Acknowledgment. The authors gratefully acknowledge the advice and encouragement of Dr. Hilliard Festenstein, and the excellent technical assistance of Mrs. Marilyn Kendrick and Mrs. Valerie Keeling.

This work has been supported by the Medical Research Council of Canada, The Cancer Research Campaign, and NIH grant AI 11962

\section{References}

Anderson, C.L. and Grey, H.M.: Receptors for aggregated IgG on mouse lymphocytes. Their presence on thymus, thymus derived lymphocytes, and bone marrow derived lymphocytes. $J$. Exp. Med. 139:1175-1188, 1974

Basten, A., Sprent, J., and Miller, J.F.A.P. : Receptor for antibody-antigen complexes used to separate T cells from B cells. Nature 253:178-180, 1972 a

Basten, A., Miller, J.F.A.P., Sprent, J., and Pyre, J.: A receptor for antibody on mouse B lymphocytes. I Method of detection and functional significance. J. Exp. Med. 135:610 626, 1972 b

Cline, M.J., Sprent, J., Warner, N.J., and Harris, A.W.: Receptors for immunoglobulin on B lymphocytes and cells of a cultured plasma cell tumor. J. Immunol. 108:1126-1128, 1972

David, C.S., Schreffler, D.C., and Frelinger, J.A.: New lymphocyte antigens controlled by the Ir region of the mouse H-2 complex. Proc. Natl. Acad. Sci. 70:2509-2514, 1973

Démant, P.: The H-2 gene complex and its role in alloimmune reactions. Transplant. Rev. 15:162-200, 1973

Dickler, H. and Sachs, D.: Evidence for the identity or close association of the Fc receptor of B lymphocytes and alloantigens determined by the Ir region of the H-2 complex. J. Exp. Med. $140: 779-796,1974$

Eden, A., Bianco, C., and Nussenzweig, V.: Mechanism of binding of soluble immune complexes to lymphocytes. Cell Immunol. $7: 459-493,1973$

Halloran, P. and Festenstein, H. Inhibition of cell-dependent cytotoxicity as an assay for mouse alloantibody. Nature 250:52-54, 1974

Halloran, P., Schirrmacher, V., and Festenstein, H. : A new sensitive assay for antibody against cell surface antigens based on inhibition of cell-dependent antibody-mediated cytotoxicity. I Specificity and sensitivity. J. Exp. Med. 140:1348-1363, 1974

Holland, P., Holland, N.H., and Cohn, Z.A.: The selective inhibition of macrophage phagocytic receptors by anti-membrane antibodies. J. Exp. Med. $135: 458-475,1972$

Kerbel, R.S. and Davies, A.J.S. : The possible biological significance of Fc receptors on mammalian lymphocytes and tumor cells. Cell 3:105-112, 1974

MacLennan, I.C.M. : Antibody in the induction and inhibition of lymphocyte cytotoxicity. Transplant. Rev. 13:67-90, 1973

McDevitt, H.O., Bechtol, K.B., Hämmerling, G.J., Lonai, P., and Delovitch, T.L.: Ir genes and antigen recognition. In E.E. Sercarz, A.R. Williamson, and C.F. Fox (eds.): The Immune System, Genes, Receptors, Signals, pp. 597-632, Academic Press, New York, 1974 
Paraskevas, F., Lee, S.-T., Orr, K.B., and Israels, L.G.: A receptor for $\mathrm{Fc}$ on mouse B lymphocytes. J. Immunol. 108:1319-1327, 1972 a

Paraskevas, F.. Orr, K.B., Anderson, E.D., Lee, S.T., and Israels, L.G.: The biological significance of the Fc receptor on mouse lymphocytes. J. Immunol. 108;1729-1732, 1972 b

Parish, C.R. and Hayward, J.A.: The lymphocyte surface. I Relation between Fe receptors, $C^{1} 3$ receptors, and surface immunoglobulin. Proc. $R$. Soc. Lond. B. 187:47-63. 1974

Schirrmacher, V., Halloran, P., Ross, E., and Festenstein, H.: A new assay for antibody against cell surface antigens based on inhibition of cell-dependent antibody-mediated lysis. II. Mechanism. Cell Immunol, in press, 1975 a

Schirrmacher, V.: Halloran. P.. and David. C.S. : Interactions of the Fc receptors with antibodies against Ia antigens and other cell surface components. J. Exp. Med., 141:1201-1209, 1975 b

Shreffler, D.C. and David, C.S.: The H-2 major histocompatibility complex and the I immune response region: genetic variation, function, and organization. Adv. Immunol. 20:125-197, 1975

Snell, G.: Catalogue of mouse alloantisera. Transplantation Immunology Branch publication. National Institute of Allergy and Infections Disease, National Institutes of Health, Bethesda. Maryland, 1968

Tøndor. A. and Thunøld, S.: Receptors for immunoglobulin Fc in human malignant tissue. Scand. J. Immunol. 2:207-215 (1973)

Yoshida, T.O. and Anderson, B. : Evidence for a receptor recognizing antigen complexed immunoglobulin on the surface of activated mouse thymus lymphocytes. Scand. J. Immunol. 1:401-408, 1972 